\title{
DISTRIBUTION OF OSTRINIA NUBILALIS HBN. EGG CLUSTERS ON MAIZE PLANTS IN SOUTH-EASTERN POLAND IN 2004-2008
}

\author{
Pawet K. Bereś* \\ Institute of Plant Protection - National Research Institute \\ Regional Experimental Station \\ Langiewicza 28, 35-101 Rzeszów, Poland
}

Received: June 3, 2011

Accepted: October 18, 2011

\begin{abstract}
The selected bionomic aspects of the European corn borer (Ostrinia nubilalis $\mathrm{Hbn}$.) on maize (Zea mays L.) were studied between 2004-2008 in Krzeczowice (49 $59^{\prime}$ N; $22^{\circ} 27^{\prime}$ E); the south-eastern region of Poland. These aspects include the reproductive behaviour as related to the location of egg clusters oviposited by females on various parts of maize plants. Information about the egg cluster distribution on maize plants may help farmers and extension staff establish the optimal period for undertaking chemical or biological control intervention. The highest number of egg clusters were recorded in the central parts of plants, on fifth to seventh leaves, and on the third and fourth internodes. The majority of eggs were oviposited on the bottom side of leaves in the middle part by the midrib.
\end{abstract}

Key words: Ostrinia nubilalis Hbn., maize, egg clusters, distribution, stems, leaves

\section{INTRODUCTION}

The European corn borer (ECB) (Ostrinia nubilalis $\mathrm{Hbn}$.) is one of the most serious maize pests in Poland (Lisowicz 2001; Wałkowski and Bubniewicz 2004; Żołnierz and Hurej 2005; Haliniarz and Bojarczyk 2007; Bereś and Konefał 2010). In regions where maize is intensively cultivated, caterpillars of this moth damage $80 \%$, and sometimes up to $100 \%$ of plants, causing up to a $40 \%$ loss in maize grain yield (Lisowicz and Tekiela 2004).

In many regions of Poland, the ECB caterpillars are sprayed and various other means are used to control them because of the amount of damage they cause to maize crop. The identification of the optimal date for chemical treatment or the introduction of Trichogramma spp., requires constant monitoring of maize cultivation for the presence of the controlled pest's development stages in the field (Bereś et al. 2007). According to the above-mentioned authors, one of the methods used for signalling the presence of ECB caterpillars is based on searching for the presence of egg clusters on maize plants. Such observations are carried out by farmers growing maize as well as the extension staff and inspectors of the State Plant Health and Seed Inspection Service (Bereś and Lisowicz 2006).

Searching for the ECB's eggs on maize plants is labourconsuming, and therefore it was necessary to identify places of female oviposition preference on various parts of the maize plant. Identification of such places should help farmers and extension staff to more effectively monitor deposition of egg clusters on maize.

\section{MATERIALS AND METHODS}

The study was conducted in 2004-2008 in the Plant Cultivation Station in Krzeczowice (49 $59^{\prime}$ N; $22^{\circ} 27^{\prime}$ E) near Przeworsk (south-eastern Poland). The observations were carried out on the San maize cultivar (FAO 240) being grown on a $5-7$ ha maize field.

To investigate the sites of egg deposition by O. nubilalis females, 50 consecutive maize plants in a row were analysed in each of four field sites (in total 200 on the field). Twice a week, observations were carried out on the presence of marked egg clusters. Observations always began in the first ten days of June, and were carried out on the same marked maize plants in the experimental field. The analyses ended three weeks later, the day after no new ECB egg clusters were found. The location of egg clusters was noted on the following plant parts:

- leaf number from the bottom of the plant;

- location of the egg cluster on the leaf part;

- internode number from the bottom of the plant.

We identified the leaf number (abbreviated as " $L$ "), and the (abbreviated as "I") where egg clusters of O. nubilalis were found as well as the precise location of the egg clusters on the leaves. For identification purposes, the leaf upper and bottom sides were divided into three major parts: the base, middle and top (Fig. 1).

In addition, three zones identified with the numbers 1, 2 and 3, were specified as follows: 


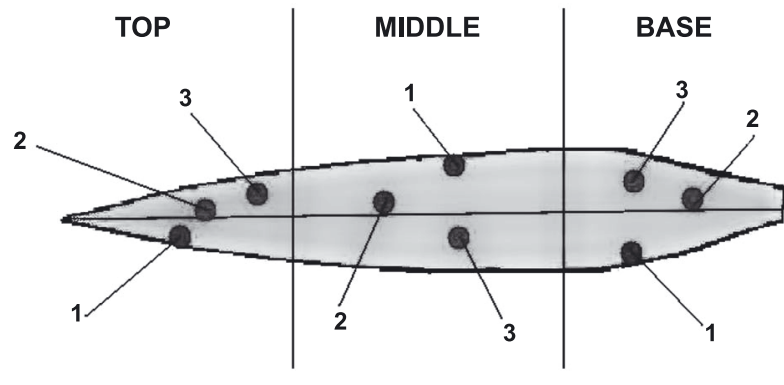

Fig. 1. Search locations for egg clusters on leaves

1. Egg cluster located near the leaf margin at a distance not greater than 1-2 $\mathrm{cm}$ from the margin (depending on leaf size).

2. Egg cluster located directly by the midrib, or at a distance not greater than $0.5-1.0 \mathrm{~cm}$ from the midrib (depending on leaf size).

3. Egg cluster located in the centre of the established leaf fragment, between the midrib and the leaf margin (between zones 1 and 2).

Depending on the location of the egg clusters on leaves, 9 combinations were established, and their characteristics are presented in table 1.

Table 1. Distribution of egg clusters on the leaf

\begin{tabular}{|c|c|c|c|}
\hline \multirow{2}{*}{$\begin{array}{c}\text { Leaf } \\
\text { part }\end{array}$} & \multicolumn{3}{|c|}{$\begin{array}{c}\text { Distribution of egg clusters } \\
\text { on the leaf in individual zones: }\end{array}$} \\
\cline { 2 - 4 } Top & 1 & 2 & 3 \\
\hline \multirow{2}{*}{ Middle } & $\begin{array}{c}\text { top on the } \\
\text { margin } \\
\text { (T1) }\end{array}$ & $\begin{array}{c}\text { top by the } \\
\text { midrib } \\
\text { (T2) }\end{array}$ & $\begin{array}{c}\text { top in the } \\
\text { centre } \\
\text { (T3) }\end{array}$ \\
\hline \multirow{3}{*}{ Base } & $\begin{array}{c}\text { middle on the } \\
\text { margin } \\
\text { (M1) }\end{array}$ & $\begin{array}{c}\text { middle by the } \\
\text { midrib } \\
\text { (Mas) }\end{array}$ & $\begin{array}{c}\text { middle in the } \\
\text { centre } \\
\text { (M3) }\end{array}$ \\
& $\begin{array}{c}\text { margin } \\
\text { (B1) }\end{array}$ & $\begin{array}{c}\text { base by the } \\
\text { midrib } \\
\text { (B2) }\end{array}$ & $\begin{array}{c}\text { base in the } \\
\text { centre } \\
\text { (B3) }\end{array}$ \\
\hline
\end{tabular}

\section{RESULTS}

\section{Places of egg cluster deposition on the leaves and stems} of maize plants

Places of egg cluster deposition by O. nubilalis females on individual leaves and internodes of maize in 20042008, are presented in table 2.

In the 2004 growing season, the majority of egg clusters were deposited between the fourth and seventh leaf (L4-L7) by ECB females. The sixth leaf (L6) was the one most preferred by females. They deposited a total of 48 egg clusters on L6, which was equal to $29.8 \%$ of all found egg clusters. This was followed by the leaf no. 5 (L5) and leaf no. seven (L7), on which the moths deposited 34 and 30 egg clusters respectively, equal to 21.1 and $18.6 \%$ of all clusters, respectively. No egg clusters were found on leaf no. 1 (L1), which is located just above the ground surface, nor on the eleventh to the thirteenth leaves (L11-L13) on the higher parts of the plants. In 2004, there were 200 plants analysed and female ECB deposited only one egg cluster on the stem, on the fourth internode (I4) representing $0.62 \%$ of the total number of all egg clusters deposited at that position (Table 2).

In 2005, O. nubilalis females preferred egg deposition on the central plant parts. Similar to the year before, moths found leaves from the fourth to the seventh (L4L7) to be the most attractive. The largest number of egg clusters (29) was found on the sixth leaf (L6), representing $20.8 \%$ of all egg clusters. On the seventh, fifth, and fourth leaves (L7, L5 and L4) we recorded 26, 25 and 23 egg clusters respectively; equal to 18.7, 17.9 and $16.5 \%$ of all egg clusters observed on the analysed plants. The lowest leaf on which $O$. nubilalis eggs were found, was leaf No. 2 (L2), where only 3 egg clusters were recorded, while the highest leaf was no. 11 (L11), where 3 clusters were also found. In 2005, ECB females deposited a total of 5 egg clusters on stems. The ECB eggs were recorded on internodes from no. 3 to no. 5 (I3, I4 and I5). The largest number of egg clusters (3) was found on the fourth internode (I4), representing $2.1 \%$ of all egg clusters deposited on 200 plants. One egg cluster was found on two other internodes, i.e. I3 and I5 (Table 2).

In the growing season 2006, O. nubilalis females deposited the largest number of egg clusters (41) on the seventh leaf (L7), representing $29.0 \%$ of all egg clusters found on 200 analysed plants. Less preferred leaves were No. 5 and 6 (L5 and L6), where 29 egg clusters were found on each. The lowest located leaf where ECB eggs were found was the third leaf (L3), while the highest location was leaf number 11 (L11). In 2006, we recorded 7 egg clusters on maize stems, which were located on the second, third and fifth internodes (I2, I3 and I5). Three egg clusters were observed on internode numbers 3 and 5 , while on internode number 2 (I2) only one egg cluster was found (Table 2).

The 2007, observations confirmed results of the previous season, where the most preferred leaf by the ECB for egg deposition was leaf number seven (L7). Moths deposited 48 egg clusters on L7, which was nearly a half (44.0\%) of all the egg clusters found that year on the analysed plants. On the sixth leaf (L6), 28 egg clusters were found (25.6\%), and $19(17.4 \%)$ on leaf number 5 (L5). In 2007, egg clusters of $O$. nubilalis were deposited by females on the fourth to the tenth leaves (L4-L10). Only one egg cluster was observed on the stem, on the third internode (I3), which was only $0.9 \%$ of the total number of egg clusters deposited on the analysed plants (Table 2).

In 2008, as in the previous years, the most preferred leaf by the ECB for egg deposition was leaf number seven (L7), where moths deposited 34 egg clusters; $37.7 \%$ of all egg clusters found that year. On the sixth and fifth leaves (L6 and L5), we found 23 (25.5\%) and 16 (17.7\%) egg clusters; respectively. The lowest located leaf above the ground; on which ECB eggs were observed, was the fourth leaf (L4), on which 4 egg clusters were found, while the highest located leaf was number 11 (L11), on which only 2 egg clusters were deposited. In 2008, only 2 egg clusters were found on maize stems, and they were oviposited (one on each) on the third and fourth internodes (I3 and I4) (Table 2). 
Table 2. Distribution of egg clusters on leaves and internodes of maize plants in 2004-2008

\begin{tabular}{|c|c|c|c|c|c|c|c|c|c|c|c|c|}
\hline \multirow{3}{*}{\multicolumn{3}{|c|}{$\begin{array}{l}\text { Distribution of egg } \\
\text { clusters }\end{array}$}} & \multicolumn{10}{|c|}{ Number of egg clusters in year: } \\
\hline & & & \multicolumn{2}{|c|}{2004} & \multicolumn{2}{|c|}{2005} & \multicolumn{2}{|c|}{2006} & \multicolumn{2}{|c|}{2007} & \multicolumn{2}{|c|}{2008} \\
\hline & & & [pcs.] & [\%] & [pcs.] & {$[\%]$} & [pcs.] & {$[\%]$} & [pcs.] & {$[\%]$} & [pcs.] & {$[\%]$} \\
\hline \multirow{13}{*}{ Leaf } & \multirow{13}{*}{$\begin{array}{c}\text { Leaf } \\
\text { number } \\
\text { (L) }\end{array}$} & 1 & 0 & 0.0 & 0 & 0.0 & 0 & 0.0 & 0 & 0.0 & 0 & 0.0 \\
\hline & & 2 & 1 & 0.62 & 3 & 2.16 & 0 & 0.0 & 0 & 0.0 & 0 & 0.0 \\
\hline & & 3 & 6 & 3.73 & 8 & 5.76 & 3 & 2.13 & 0 & 0.0 & 0 & 0.0 \\
\hline & & 4 & 21 & 13.04 & 23 & 16.55 & 7 & 4.96 & 3 & 2.75 & 4 & 4.44 \\
\hline & & 5 & 34 & 21.12 & 25 & 17.99 & 29 & 20.57 & 19 & 17.43 & 16 & 17.78 \\
\hline & & 6 & 48 & 29.81 & 29 & 20.86 & 29 & 20.57 & 28 & 25.69 & 23 & 25.57 \\
\hline & & 7 & 30 & 18.63 & 26 & 18.71 & 41 & 29.08 & 48 & 44.04 & 34 & 37.78 \\
\hline & & 8 & 13 & 8.07 & 11 & 7.91 & 12 & 8.51 & 5 & 4.59 & 3 & 3.33 \\
\hline & & 9 & 5 & 3.12 & 6 & 4.33 & 5 & 3.55 & 3 & 2.75 & 3 & 3.33 \\
\hline & & 10 & 2 & 1.24 & 0 & 0.0 & 3 & 2.13 & 2 & 1.83 & 3 & 3.33 \\
\hline & & 11 & 0 & 0.0 & 3 & 2.16 & 5 & 3.55 & 0 & 0.0 & 2 & 2.22 \\
\hline & & 12 & 0 & 0.0 & 0 & 0.0 & 0 & 0.0 & 0 & 0.0 & 0 & 0.0 \\
\hline & & 13 & 0 & 0.0 & 0 & 0.0 & 0 & 0.0 & 0 & 0.0 & 0 & 0.0 \\
\hline \multirow{5}{*}{ Stem } & \multirow{5}{*}{$\begin{array}{l}\text { Internode } \\
\text { number } \\
\text { (I) }\end{array}$} & 1 & 0 & 0.0 & 0 & 0.0 & 0 & 0.0 & 0 & 0.0 & 0 & 0.0 \\
\hline & & 2 & 0 & 0.0 & 0 & 0.0 & 1 & 0.69 & 0 & 0.0 & 0 & 0.0 \\
\hline & & 3 & 0 & 0.0 & 1 & 0.71 & 3 & 2.13 & 1 & 0.92 & 1 & 1.11 \\
\hline & & 4 & 1 & 0.62 & 3 & 2.15 & 0 & 0.0 & 0 & 0.0 & 1 & 1.11 \\
\hline & & 5 & 0 & 0.0 & 1 & 0.71 & 3 & 2.13 & 0 & 0.0 & 0 & 0.0 \\
\hline \multicolumn{3}{|c|}{ Total } & 161 & 100.0 & 139 & 100.0 & 141 & 100.0 & 109 & 100.0 & 90 & 100.0 \\
\hline
\end{tabular}

L - leaves; I - internode

In all the study years, no egg clusters of the European corn borer were found on the lowest leaf above the ground, identified as L1, nor on the leaves located near the tassel, identified as L12 and L13. No egg clusters were found on the stems on the first internode (I1) or internodes higher than the fifth (I5).

\section{Distribution of egg clusters on the leaf}

In the growing season, the highest number of egg clusters (147) were deposited on the bottom side of maize leaves, representing $91.8 \%$ of all egg clusters oviposited on the leaves. Only 13 egg clusters $(8.1 \%)$ were found on the upper side of the leaves (Table 3). From among all egg clusters deposited on the bottom side of leaves, as many as $77(52.3 \%)$ were found in the middle part the midrib (M2). A much less preferred location by the females was the middle of the leaf on the margin (M1), where $26 \mathrm{egg}$ clusters were observed (17.6\%), and the leaf base by the midrib (B2), where 22 egg clusters were found (14.9\%). On the upper side of the leaf, a particularly preferred location for egg deposition was the leaf base on the margin (B1), where a total of 5 egg clusters were found (38.4\%), and the middle of the leaf on the margin (M1), where 4 egg clusters were found (30.7\%) (Table 3).

In 2005 , as many as $94.0 \%$ of all egg clusters were located on the bottom side of leaves, and only $5.9 \%$ on the upper side (Table 4). On the bottom side of the leaves, O. nubilalis females mainly preferred the middle part of the leaf by the midrib (M2), where they deposited a total of 51 egg clusters, equal to $40.4 \%$ of all egg clusters found on the bottom side of the leaves. A significantly lower number of egg clusters were recorded on the leaf base by the midrib (B2), in the middle part of the margin (M1), and on the leaf base on the margin (B1), where we found 27, 14 and 12 egg clusters respectively, which accounted for $21.4,11.1$ and $9.5 \%$ of all egg clusters found on the bottom side of the leaves. On the upper side of the leaf, similar to the 2004 observations, the most preferred location for egg deposition was the leaf base on the margin (B1), where females deposited a total of 4 egg clusters, which made up $50.0 \%$ of all egg clusters found on the upper side of the leaf (Table 4).

In 2006, from among all 134 egg clusters found on the leaves, as many as $91.8 \%$ were located on the bottom side, and only $8.2 \%$ on the upper side of the leaves (Table 5). The most preferred location by females for oviposition on the bottom side of the leaves was the middle of the leaf by the midrib (M2), where they deposited a total of 60 egg clusters; equal to $48.7 \%$ of all egg clusters found on the bottom side of the leaves. Similar to previous years, females also frequently deposited eggs on the leaf base by the midrib (B2), where a total of 24 egg clusters were found $(19.5 \%)$. On the upper side of the leaves, the highest number of egg clusters were found in the middle part between the midrib and the leaf margin (M3), where a total of 6 egg clusters were found; $54.5 \%$ of the total number of egg clusters deposited on the upper side (Table 5).

In 2007, from among all 108 egg clusters found on the leaves of the analysed plants, there were as many as 99; i.e. $91.6 \%$ were located on the bottom side of the leaves, and only $9(8.3 \%)$ were found on the upper side (Table 6 ). On the bottom side of the leaves, the highest number of egg clusters, i.e. $56(56.5 \%)$ were found in the middle of the leaf by the midrib (M2). A significantly lower number of egg clusters (14) were recorded on the leaf base by the midrib (B2), and 13 egg clusters were recorded in the 
Table 3. Distribution of egg clusters on the leaves in 2004

\begin{tabular}{|c|c|c|c|c|}
\hline \multirow{2}{*}{ Leaf } & \multirow{2}{*}{ Distribution of egg clusters } & \multicolumn{2}{|c|}{ Number of egg clusters } & \multirow{2}{*}{$\begin{array}{c}\text { Total per cent share } \\
{[\%]}\end{array}$} \\
\hline & & [pcs.] & [\%] & \\
\hline \multirow{9}{*}{ Bottom side } & top on the margin (T1) & 3 & 2.04 & 1.88 \\
\hline & top by the midrib (T2) & 11 & 7.48 & 6.88 \\
\hline & top in the centre (T3) & 0 & 0.0 & 0.0 \\
\hline & middle on the margin (M1) & 26 & 17.69 & 16.24 \\
\hline & middle by the midrib (M2) & 77 & 52.38 & 48.12 \\
\hline & middle in the centre (M3) & 0 & 0.0 & 0.0 \\
\hline & base on the margin (B1) & 8 & 5.44 & 5.0 \\
\hline & base by the midrib (B2) & 22 & 14.97 & 13.75 \\
\hline & base in the centre (B3) & 0 & 0.0 & 0.0 \\
\hline \multicolumn{2}{|l|}{ Total } & 147 & 100.0 & 91.87 \\
\hline \multirow{9}{*}{ Upper side } & top on the margin (T1) & 1.0 & 7.69 & 0.63 \\
\hline & top by the midrib (T2) & 0 & 0.0 & 0.0 \\
\hline & top in the centre (T3) & 0 & 0.0 & 0.0 \\
\hline & middle on the margin (M1) & 4 & 30.77 & 2.50 \\
\hline & middle by the midrib (M2) & 2 & 15.38 & 1.25 \\
\hline & middle in the centre (M3) & 0 & 0.0 & 0.0 \\
\hline & base on the margin (B1) & 5 & 38.46 & 3.12 \\
\hline & base by the midrib (B2) & 1 & 7.70 & 0.63 \\
\hline & base in the centre (B3) & 0 & 0.0 & 0.0 \\
\hline \multicolumn{2}{|l|}{ Total } & 13 & 100.0 & 8.13 \\
\hline \multicolumn{2}{|c|}{ Total number of egg clusters on the leaves } & 160 & - & 100.0 \\
\hline
\end{tabular}

Table 4. Distribution of egg clusters on the leaves in 2005

\begin{tabular}{|c|c|c|c|c|}
\hline \multirow{2}{*}{ Leaf } & \multirow{2}{*}{ Distribution of egg clusters } & \multicolumn{2}{|c|}{ Number of egg clusters } & \multirow{2}{*}{$\begin{array}{c}\text { Total per cent share } \\
{[\%]}\end{array}$} \\
\hline & & [pcs.] & [\%] & \\
\hline \multirow{9}{*}{ Bottom side } & top on the margin (T1) & 3 & 2.38 & 2.24 \\
\hline & top by the midrib (T2) & 4 & 3.17 & 2.99 \\
\hline & top in the centre (T3) & 1 & 0.79 & 0.75 \\
\hline & middle on the margin (M1) & 14 & 11.11 & 10.44 \\
\hline & middle by the midrib (M2) & 51 & 40.48 & 38.05 \\
\hline & middle in the centre (M3) & 8 & 6.35 & 5.97 \\
\hline & base on the margin (B1) & 12 & 9.52 & 8.96 \\
\hline & base by the midrib (B2) & 27 & 21.44 & 20.15 \\
\hline & base in the centre (B3) & 6 & 4.76 & 4.48 \\
\hline \multicolumn{2}{|l|}{ Total } & & 100.0 & 94.03 \\
\hline \multirow{9}{*}{ Upper side } & top on the margin (T1) & 0 & 0.0 & 0.0 \\
\hline & top by the midrib (T2) & 0 & 0.0 & 0.0 \\
\hline & top in the centre (T3) & 0 & 0.0 & 0.0 \\
\hline & middle on the margin (M1) & 1 & 12.5 & 0.75 \\
\hline & middle by the midrib (M2) & 1 & 12.5 & 0.75 \\
\hline & middle in the centre (M3) & 0 & 0.0 & 0.0 \\
\hline & base on the margin (B1) & 4 & 50.0 & 2.97 \\
\hline & base by the midrib (B2) & 1 & 12.5 & 0.75 \\
\hline & base in the centre (B3) & 1 & 12.5 & 0.75 \\
\hline \multicolumn{2}{|l|}{ Total } & & 100.0 & 5.97 \\
\hline \multicolumn{2}{|c|}{ Total number of egg clusters on the leaves } & & - & 100.0 \\
\hline
\end{tabular}


Table 5. Distribution of egg clusters on the leaves in 2006

\begin{tabular}{|c|c|c|c|c|}
\hline \multirow{2}{*}{ Leaf } & \multirow{2}{*}{ Distribution of egg clusters } & \multicolumn{2}{|c|}{ Number of egg clusters } & \multirow{2}{*}{$\begin{array}{c}\text { Total per cent share } \\
{[\%]}\end{array}$} \\
\hline & & [pcs.] & {$[\%]$} & \\
\hline \multirow{9}{*}{ Bottom side } & top on the margin (T1) & 1 & 0.81 & 0.75 \\
\hline & top by the midrib (T2) & 0 & 0.0 & 0.0 \\
\hline & top in the centre (T3) & 4 & 3.25 & 2.99 \\
\hline & middle on the margin (M1) & 4 & 3.25 & 2.99 \\
\hline & middle by the midrib (M2) & 60 & 48.79 & 44.77 \\
\hline & middle in the centre (M3) & 17 & 13.82 & 12.69 \\
\hline & base on the margin (B1) & 3 & 2.44 & 2.24 \\
\hline & base by the midrib (B2) & 24 & 19.51 & 17.91 \\
\hline & base in the centre (B3) & 10 & 8,13 & 7.46 \\
\hline \multicolumn{2}{|l|}{ Total } & & 100.0 & 91.8 \\
\hline \multirow{9}{*}{ Upper side } & top on the margin (T1) & 0 & 0.0 & 0.0 \\
\hline & top by the midrib (T2) & 0 & 0.0 & 0.0 \\
\hline & top in the centre (T3) & 0 & 0.0 & 0.0 \\
\hline & middle on the margin (M1) & 2 & 18.18 & 1.5 \\
\hline & middle by the midrib (M2) & 1 & 9.09 & 0.75 \\
\hline & middle in the centre (M3) & 6 & 54.55 & 4.5 \\
\hline & base on the margin (B1) & 0 & 0.0 & 0.0 \\
\hline & base by the midrib (B2) & 0 & 0.0 & 0.0 \\
\hline & base in the centre (B3) & 2 & 18.18 & 1.49 \\
\hline \multicolumn{2}{|l|}{ Total } & & 100.0 & 8.2 \\
\hline \multicolumn{2}{|c|}{ Total number of egg clusters on the leaves } & & - & 100.0 \\
\hline
\end{tabular}

Table 6. Distribution of egg clusters on the leaves in 2007

\begin{tabular}{|c|c|c|c|c|}
\hline \multirow{2}{*}{ Leaf } & \multirow{2}{*}{ Distribution of egg clusters } & \multicolumn{2}{|c|}{ Number of egg clusters } & \multirow{2}{*}{$\begin{array}{c}\text { Total per cent share } \\
{[\%]}\end{array}$} \\
\hline & & [pcs.] & {$[\%]$} & \\
\hline \multirow{9}{*}{ Bottom side } & top on the margin (T1) & 1 & 1.01 & 0.93 \\
\hline & top by the midrib (T2) & 4 & 4.04 & 3.70 \\
\hline & top in the centre (T3) & 2 & 2.02 & 1.85 \\
\hline & middle on the margin (M1) & 7 & 7.07 & 6.48 \\
\hline & middle by the midrib (M2) & 56 & 56.57 & 51.85 \\
\hline & middle in the centre (M3) & 13 & 13.13 & 12.04 \\
\hline & base on the margin (B1) & 0 & 0.0 & 0.0 \\
\hline & base by the midrib (B2) & 14 & 14.14 & 12.96 \\
\hline & base in the centre (B3) & 2 & 2.02 & 1.85 \\
\hline \multicolumn{2}{|l|}{ Total } & & 100.0 & 91.66 \\
\hline \multirow{9}{*}{ Upper side } & top on the margin (T1) & 0 & 0.0 & 0.0 \\
\hline & top by the midrib (T2) & 0 & 0.0 & 0.0 \\
\hline & top in the centre (T3) & 0 & 0.0 & 0.0 \\
\hline & middle on the margin (M1) & 2 & 22.22 & 1.85 \\
\hline & middle by the midrib (M2) & 1 & 11.11 & 0.93 \\
\hline & middle in the centre (M3) & 6 & 66.67 & 5.56 \\
\hline & base on the margin (B1) & 0 & 0.0 & 0.0 \\
\hline & base by the midrib (B2) & 0 & 0.0 & 0.0 \\
\hline & base in the centre (B3) & 0 & 0.0 & 0.0 \\
\hline \multicolumn{2}{|l|}{ Total } & & 100.0 & 8.34 \\
\hline \multicolumn{2}{|c|}{ Total number of egg clusters on the leaves } & & - & 100.0 \\
\hline
\end{tabular}


Table 7. Distribution of egg clusters on the leaves in 2008

\begin{tabular}{|c|c|c|c|c|}
\hline \multirow{2}{*}{ Leaf } & \multirow{2}{*}{ Distribution of egg clusters } & \multicolumn{2}{|c|}{ Number of egg clusters } & \multirow{2}{*}{$\begin{array}{c}\text { Total per cent share } \\
{[\%]}\end{array}$} \\
\hline & & [pcs.] & {$[\%]$} & \\
\hline \multirow{9}{*}{ Bottom side } & top on the margin (T1) & 1 & 1.20 & 1.14 \\
\hline & top by the midrib (T2) & 0 & 0.0 & 0.0 \\
\hline & top in the centre (T3) & 2 & 2.41 & 2.27 \\
\hline & middle on the margin (M1) & 9 & 10.85 & 10.23 \\
\hline & middle by the midrib (M2) & 51 & 61.46 & 57.95 \\
\hline & middle in the centre (M3) & 11 & 13.25 & 12.50 \\
\hline & base on the margin (B1) & 3 & 3.61 & 3.41 \\
\hline & base by the midrib (B2) & 5 & 6.02 & 5.68 \\
\hline & base in the centre (B3) & 1 & 1.20 & 1.14 \\
\hline \multicolumn{2}{|l|}{ Total } & & 100.0 & 94.32 \\
\hline \multirow{9}{*}{ Upper side } & top on the margin (T1) & 0 & 0.0 & 0.0 \\
\hline & top by the midrib (T2) & 0 & 0.0 & 0.0 \\
\hline & top in the centre (T3) & 0 & 0.0 & 0.0 \\
\hline & middle on the margin (M1) & 2 & 40.0 & 2.26 \\
\hline & middle by the midrib (M2) & 1 & 20.0 & 1.14 \\
\hline & middle in the centre (M3) & 1 & 20.0 & 1.14 \\
\hline & base on the margin (B1) & 1 & 20.0 & 1.14 \\
\hline & base by the midrib (B2) & 0 & 0.0 & 0.0 \\
\hline & base in the centre (B3) & 0 & 0.0 & 0.0 \\
\hline \multicolumn{2}{|l|}{ Total } & & 100.0 & 5.68 \\
\hline \multicolumn{2}{|c|}{ Total number of egg clusters on the leaves } & & - & 100.0 \\
\hline
\end{tabular}

middle of the leaf between the midrib and the leaf margin (M3). On the upper side of the leaves the highest number of egg clusters (6) were deposited by females in the middle part in the centre (M3), representing $66.6 \%$ of all egg clusters found on that side of the leaves (Table 6).

In 2008, similar to previous years, the highest number of egg clusters (83) were deposited by O. nubilalis females on the bottom side of the leaves, and only 5 egg clusters on the upper side (Table 7). From among all egg clusters deposited on the bottom side of leaves, as many as $61.4 \%$ were found in the middle part of the leaf by the midrib (M2). Another location preferred by ECB moths in 2008, was also the middle of the leaf in the centre (M3), where 11 egg clusters were deposited, which was $13.2 \%$ of the total number of clusters found on the bottom side of the leaves that year. On the upper side of the maize leaves, egg clusters were deposited mainly in the middle part (Table 7).

\section{DISCUSSION}

Information about the most frequent location of egg clusters of the European corn borer (O. nubilalis) found on maize, is essential for farmers growing this crop, and for inspectors providing advise and signalling the dates for control interventions of this pest. The presented data on the oviposition preference of the ECB females for egg laying will help to establish the optimal date for biological treatment and/or chemical control (Bereś et al. 2007). Our data should also assist in the implementation of the economic injury (i.e. 6-8 egg clusters per 100 plants), when the decision is made to use chemical spraying (Bereś and Pruszyński 2008).

Only a few authors have conducted detailed studies in Poland on the preferences of O. nubilalis females with respect to oviposition on particular maize leaves and stem internodes. There are few studies which focus especially on detailed identification of egg cluster distribution on leaves.

Such studies on sweet corn have only been conducted by Mazurek et al. (2003), while Pieprzyk and Romankow (1960) conducted incomplete one-year observations on fodder maize.

The results of our observations indicated that the highest number of egg clusters (91.8-94.3\%) are deposited by ECB females on the bottom side of leaves. Our indications were also confirmed by other authors, [e.g. Poos (1927); Pieprzyk and Romankow (1960); Ismail (1989); Capinera (2000); Lisowicz and Tekiela (2004)]. In our studies, out of all the egg clusters deposited, 5.68-9.34\% were located on the upper side of leaves. Pieprzyk and Romankow (1960) made similar observations from out of $125 \mathrm{egg}$ clusters of O. nubilalis on maize leaves in studies by Ismail (1989), egg clusters on the upper side of leaves accounted for $20.9 \%$ of all clusters found on plants.

Furthermore, it was observed that moths preferred oviposition in the central parts of plants, most frequently on leaves near the maize cobs. During the study years, the highest number of egg clusters were recorded between the fifth and seventh leaves from the bottom of the plant. A similar preference for the deposition of a higher number of eggs on the sixth and seventh leaves was observed 
by Calvin et al. (1986). Also, Ismail (1989) and Pieprzyk and Romankow (1960) found the highest number of the ECB eggs to be located at about the middle of the plant, between the sixth and tenth leaves, with the eighth leaf being the most preferred. Suverkropp et al. (2008) suggested that the location of egg clusters on the central parts of plants may result from the horizontal migration of moths between maize plants.

In our study, the highest number of egg clusters were deposited by moths in the middle part of the leaf; most frequently by the midrib (which accounted for $44.7-57.9 \%$ of all egg clusters found on the leaves), on the leaf margin $(2.2-16.2 \%)$ and between the midrib and leaf margin (up to $12.6 \%$ ). Another highly attractive place was the leaf base by the midrib, where during the study years ECB females deposited from 5.6 to $20.1 \%$ of all egg clusters found on the leaves. Our own observations confirmed the results of other authors. According to Suverkropp et al. (2008) [quoting Klinger (1979) and Vierling (1985)], O. nubilalis moths deposit from 40.0 to $49.0 \%$ of egg clusters in the middle of the leaf, $22.0-42.0 \%$ on the leaf base, and $16.0-18.0 \%$ on the top part of the leaf.

In the conducted studies, egg clusters were also found on maize stems, but this plant part was a considerably less attractive location for oviposition than leaves. Fiveyear observations demonstrated that only from 0.6 to $2.1 \%$ of all found egg clusters of $O$. nubilalis on 200 analysed plants, were located on stems. Other authors also observed the low attractiveness of maize stems for females depositing eggs. According to Coll and Bottrell (1991) and Suverkropp et al. (2008) [quoting Everly (1959)], usually up to $6.0 \%$ of egg clusters are found on maize stems. Fiala et al. (1985) quoted by Suverkropp et al. (2008) suggested that the higher number of egg clusters located on leaves than on stems may result from the higher glucose content in the leaves. The high glucose content influences the increased oviposition by ECB females on these organs.

\section{CONCLUSIONS}

1. The field observations confirmed that O. nubilalis females deposited egg clusters between the second and eleventh leaves from the bottom of the plant, while on stems egg clusters were deposited between the second and fifth internodes.

2. The highest number of egg clusters were oviposited in the central parts of plants from the fifth to the seventh leaves and on the third and fourth internodes.

3. The highest number of egg clusters were deposited by females on the bottom side of leaves - in the middle part by the midrib, but also on the leaf base by the midrib. On the upper side of leaves, egg clusters were mainly found in the middle part of the leaf - both by the midrib and on the leaf margin.

\section{REFERENCES}

Bereś P.K., Konefał T. 2010. Distribution range of the European corn borer (Ostrinia nubilalis Hbn.) on maize in 2004-2008 in Poland. J. Plant Protection Res. 50 (3): 326-334.
Bereś P.K., Pruszyński G. 2008. Ochrona kukurydzy przed szkodnikami w produkcji integrowanej. Acta Sci. Pol., Agricultura 7 (4): 19-32.

Bereś P., Korbas M., Walczak F., Węgorek P., Złotowski J. 2007. Poradnik Sygnalizatora Ochrony Zbóż. Wyd. Inst. Ochr. Roślin, Poznań, 111 pp.

Bereś P.K., Lisowicz F. 2006. Omacnica prosowianka - Ostrinia nubilalis Hbn. Aneks do Instrukcji dla służby ochrony roślin z zakresu prognoz, sygnalizacji i rejestracji (F. Walczak, ed.). Vol. II, issue I i II (1993): „Metody Sygnalizacji i Prognozowania Pojawu Chorób i Szkodników Roślin" and vol. III (1976): „Rejestracja Ogólna i Szczegółowa Chorób i Szkodników Roślin Uprawnych". Poznań 1998, 47 pp.

Capinera J.L. 2000. European corn borer - Ostrinia nubilalis Hubner. University of Florida, Institute of Food and Agricultural Sciences. Publication number: EENY-156. http://entnemdept.ufl.edu/creatures/field/E_corn_borer.htm

Calvin D.D., Knapp M.C., Xingquan K., Poston F.L., Welch S.M. 1986. Using a decision model to optimize European corn borer (Lepidoptera: Pyralidae) egg-mass sampling. Environ. Entomol. 15: 1212-1219.

Coll M., Bottrell D.G. 1991. Microhabitat and resource selection of the European corn borer (Lepidoptera: Pyralidae) and its natural enemies in Maryland field corn. Environ. Entomol. 20 (2): 526-533.

Everly R.T. 1959. Influence of height and stage of development of dent corn on oviposition by European corn borer moth. Ann. Entomol. Soc. Am. 52: 272-279.

Fiala V., Deedidj S., Jolivet E. 1985. Influence de la teneur en glucides solubles des feuilles de Zea mays L. sur le choix de site de ponte de la pyrale, Ostrinia nubilalis $\mathrm{Hbn}$. (Lepidoptera: Pyralidae). Agronomie 5 (10): 927-932.

Haliniarz M., Bojarczyk M. 2007. Szkodliwość omacnicy prosowianki (Ostrinia nubilalis $\mathrm{Hbn}$.) dla transgenicznych i wyjściowych odmian kukurydzy. [Harmfulness of the European corn borer (Ostrinia nubilalis $\mathrm{Hbn}$.) on transgenic and non-transgenic maize varietes]. Prog. Plant Protection/ Post. Ochr. Roślin 47 (4): 145-148.

Ismail I.I. 1989. Field observations on the oviposition behaviour of different corn borers and estimation of economic thresholds. Acta Phyt. Entomol. Hung. 24 (1-2): 111-116.

Klinger S. 1979. Untersuchungen über Räumliche Verteilung der Eigelege und Verhalten, Sowie Aufenthaltsort der Jungraupen des Maiszünslers Ostrinia nubilalis. Diplomarbeit, Universität Hohenheim, Germany, 85 pp.

Lisowicz F. 2001. The occurrence of economically important maize pests in south-eastern Poland. J. Plant Protection Res. 41 (3): 250-255.

Lisowicz F., Tekiela A. 2004. Szkodniki i choroby kukurydzy oraz ich zwalczanie. p. 52-64. In: „Technologia Produkcji Kukurydzy" [Maize Production Technology] (A. Dubas, ed.). Wieś Jutra, Warszawa, 133 pp.

Mazurek J., Hurej M., Jackowski J. 2003. Some aspects of the biology of the European corn borer (Ostrinia nubilalis $\mathrm{Hbn}$.) on sweet corn. J. Plant Protection Res. 43 (4): 345-352.

Pieprzyk W., Romankow W. 1960. Wyniki jednorocznych obserwacji nad biologią omacnicy prosowianki (Pyrausta nubilalis Hbn., Lepidoptera, Tortricidae). Biul. Inst. Ochr. Roślin 9: 127-139. 
Poos F.W. 1927. Biology of the European corn borer (Pyrausta nubilalis Hübn.) and two closely related species in northern Ontario. Ohio J. Sci. 27 (2): 47-94.

Suverkropp B.P., Dutton A., Bigler F., Van Lenteren J.C. 2008. Oviposition behaviour and egg distribution of the European corn borer, Ostrinia nubilalis, on maize, and its effect on host finding by Trichogramma egg parasitoids. Bull. Insect. 61 (2): 303-312.

Vierling R. 1985. Ermittlung des Günstigsten Freilassungstermins für zur Bekämpfung des Maiszünslers auf der Filderebe. Msc. Thesis, Universität Hohenheim, Germany, 62 pp.
Wałkowski W., Bubniewicz P. 2004. Omacnica prosowianka (Ostrinia nubilalis $\mathrm{Hbn}$.) - ekspansywny szkodnik kukurydzy w Wielkopolsce. [European corn borer (Ostrinia nubilalis $\mathrm{Hbn}$.) - an expansive pest ofmaize in Wielkopolska region]. Prog. Plant Protection/Post. Ochr. Roślin 44 (2): 1187-1190.

Żołnierz R., Hurej M. 2005. Występowanie omacnicy prosowianki (Ostrinia nubilalis $\mathrm{Hbn}$.) na plantacji kukurydzy nasiennej na terenie województwa opolskiego. [Infestation of corn grown for seeds by the European corn borer (Ostrinia nubilalis Hbn.) in Opole province]. Prog. Plant Protection/ Post. Ochr. Roślin 45 (2): 1233-1236. 